\title{
Constructional effects of non-visual evidential marking in Harakmbut
}

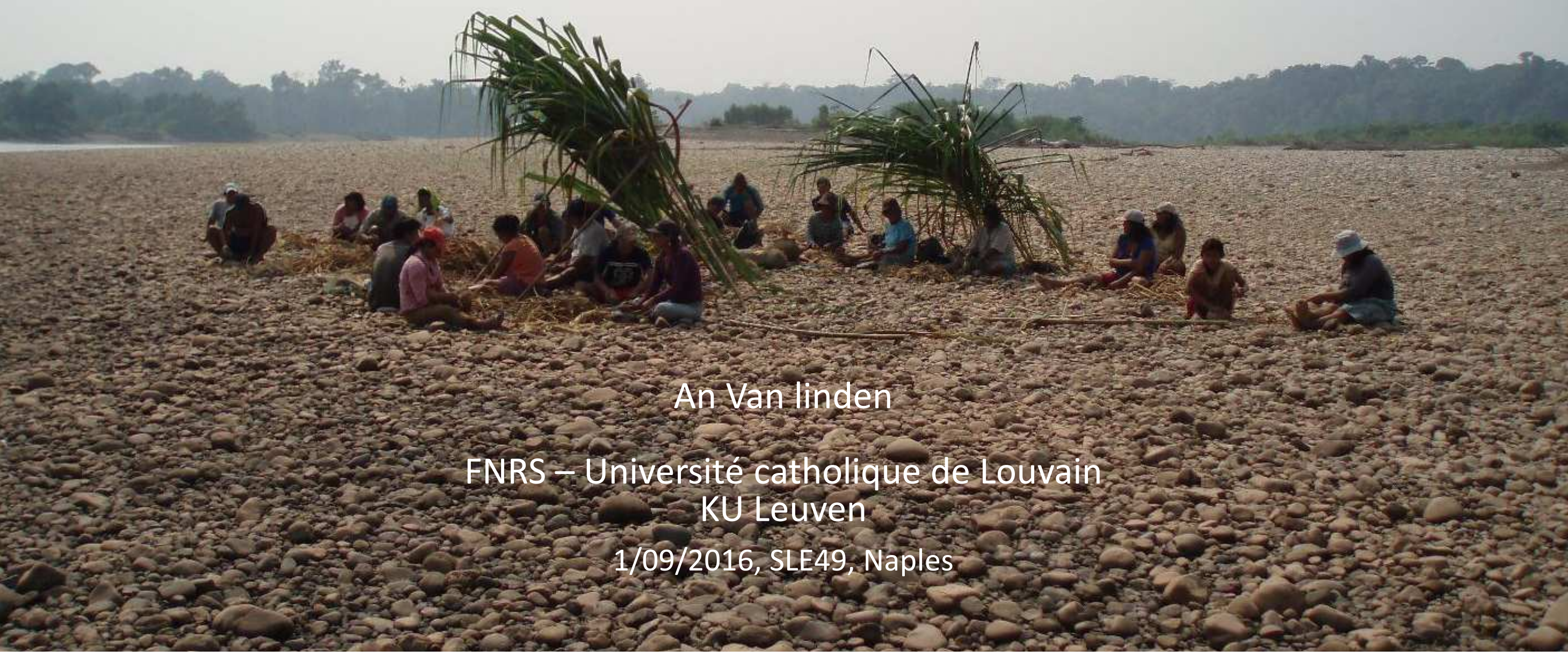




\section{Introduction}

- Harakmbut is a language from the Peruvian Amazon, spoken in 'native communities' in the departments of Madre de Dios and Cusco

- Genetic affiliation:

- Formerly classified as an Arawakan or Maipuran language by McQuown (1955) (see Hart 1963: 6) and Matteson (1972); but this has found little acceptance (Adelaar 2007: 39).

-Wise (1999: 307) states that Harakmbut is commonly accepted to be a (single language) isolate/unclassified language (cf. Fonseca 2002; Vergara 2007; WALS)

- Adelaar $(2000,2007)$ proposes that it is genetically related to the Brazilian Katukina family (included in Guaporé-Mamoré linguistic area), which may be further linked to Macro-Ge

- Areality:

- Some grammatical features are shared with Maipuran Arawak languages, and others with Tacanan languages like Ese Eja (Pozzi-Escot 1998: 93) and Cavineña (Van linden in prep); the latter are proposed to belong to the Guaporé-Mamoré linguistic area in southwest Brazil and eastern Bolivia, close to the border with Peru (Crevels \& van der Voort 2008) 
- Harakmbut live in 'native communities': patches of land entitled to them by the government

- subtropical climate

- around tributaries of the Madre de Dios River, which eventually flows into the Amazon River;

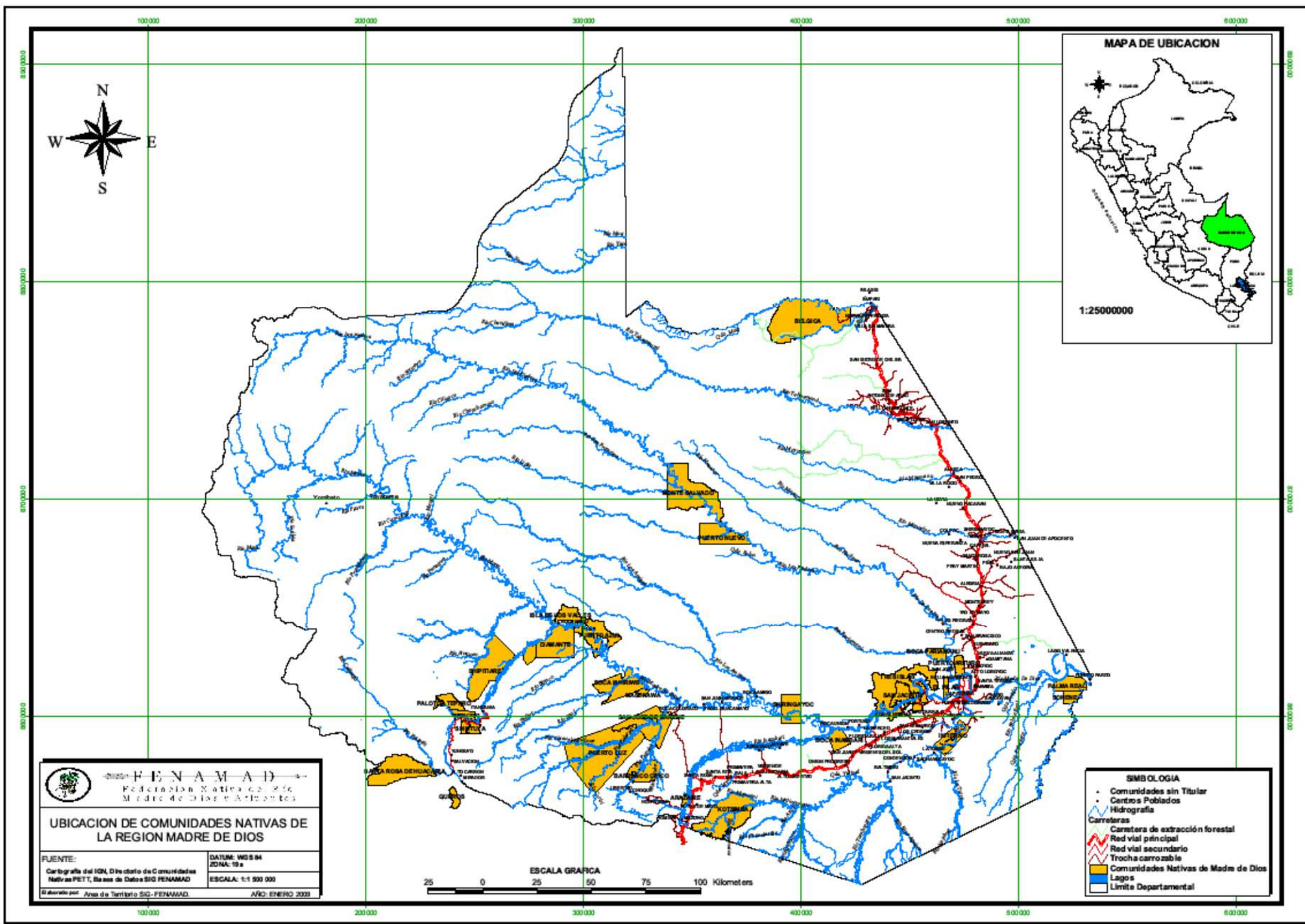




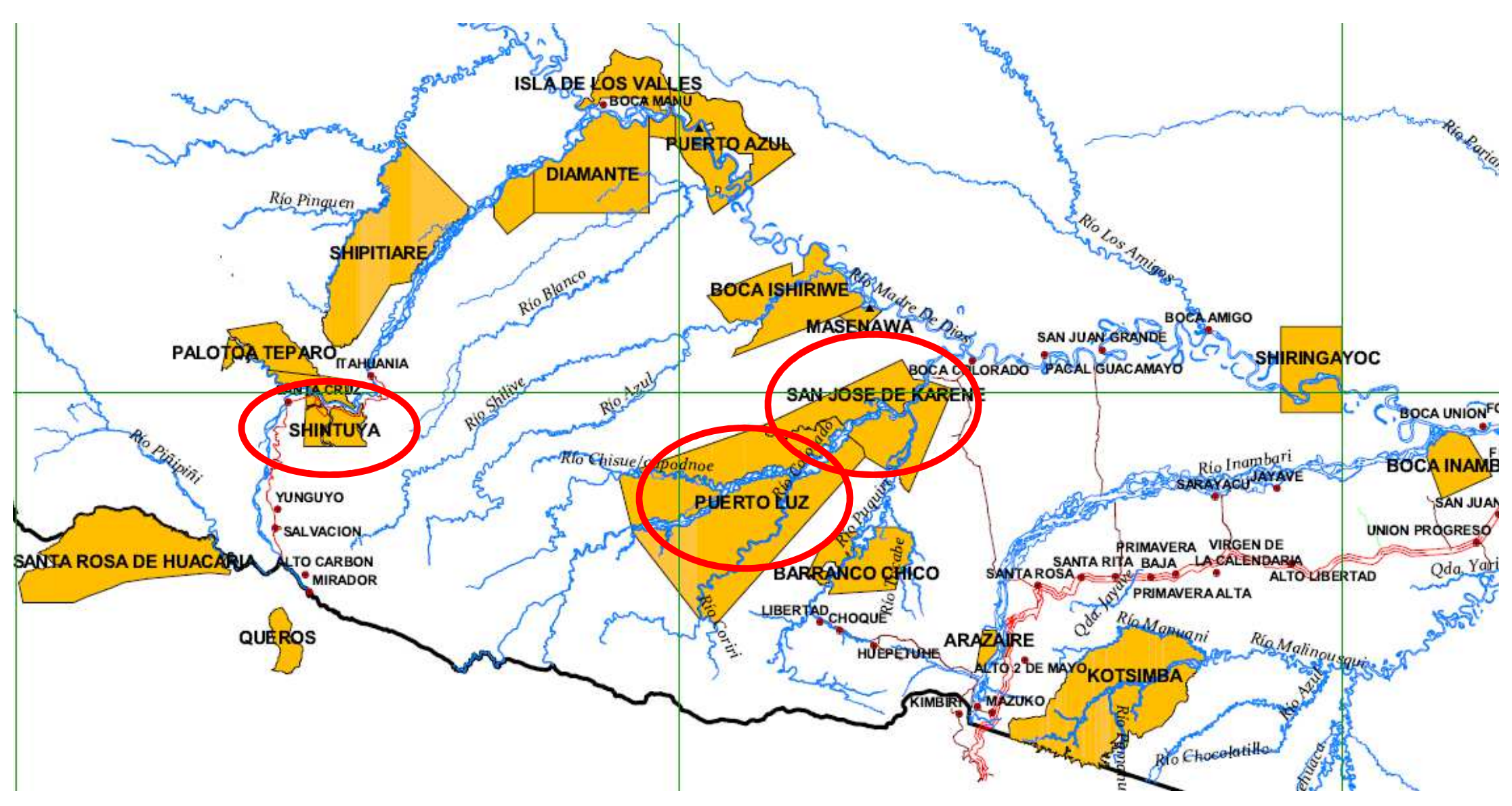

Fieldwork in Puerto Luz, San Jose de Karene and Shintuya 


\section{Introduction}

- Dialectal varieties (mutually intelligible): Amarakaeri, Watipaeri, Arasaeri, Pukirieri, Sapiteri, Kisambaeri and Toyoeri

- Previous linguistic work: focus on Amarakaeri dialect (Hart 1963; Helberg 1984, 1990; Tripp 1976ab, 1995)

- Own work: audio recording during 3 fieldwork stays in Puerto Luz, San José and Shintuya in JulAug 2010, Aug-Sept 2011, Aug 2016: all Amarakaeri informants

- Orthographic conventions: $\langle$ '>: glottal stop; $\langle "\rangle$ : nasal vowel; underlined sounds carry word stress

- today's TOPIC: Two types of constructional effects of non-visual evidential marking

- both types originate in clash in interpretation: use of non-visual marking indicates a shift away from the speaker, while events referred to ('normally') are clearly visible 


\section{Outline}

1. Introduction

2. The Harakmbut finite verb form and evidentiality

3. Effect 1: NVIS $+1^{\text {st }}$ person Agent $\rightarrow$ involuntary action

4. Effect 2: NVIS + impers. pred. $\rightarrow$ completion

5. Conclusion 


\section{Harakmbut finite verb form and evidentiality}

- Table 1: verbal plural marker (VPL) and a set of adverbial prefixes are positionally flexible, entertaining scopal relations with fixed-position prefixes.

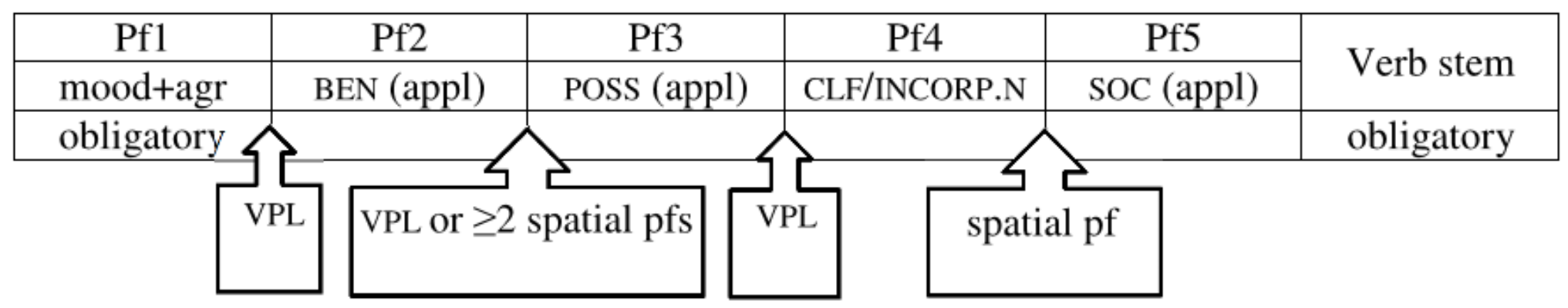

Table 1: The prefix (Pf) string of Harakmbut finite verb forms

\begin{tabular}{|l|l|l|l|l|l|l|l|}
\hline \multirow{2}{*}{$\begin{array}{l}\text { Verb } \\
\text { stem }\end{array}$} & Sf1 & Sf2 & Sf3 & Sf4 & Sf5 & Sf6 & Sf7 \\
\cline { 2 - 7 } obligatory & Asp1 & TRVR & Asp2/AM & ANA & Asp3 & Tense & mood+agr; mod; evid \\
\hline & & & & \multicolumn{3}{|c|}{$\begin{array}{l}\text { obligatory (but zero exponence } \\
\text { possible) }\end{array}$} \\
\hline
\end{tabular}

Table 2: The suffix (Sf) string of Harakmbut finite verb forms (cf. Tripp 1976a) 


\section{Harakmbut finite verb form and evidentiality}

- Table 1: verbal plural marker (VPL) and a set of adverbial prefixes are positionally flexible, entertaining scopal relations with fixed-position prefixes.

\begin{tabular}{|c|c|c|c|c|c|}
\hline Pf1 & Pf2 & Pf3 & Pf4 & Pf5 & \multirow{2}{*}{ Verb stem } \\
\hline mood+agr & BEN (appl) & POSS (appl) & CLF/INCORP.N & SOC (appl) & obligatory \\
\hline obligatory & & &
\end{tabular}

Table 1: The prefix (Pf) string of Harakmbut finite verb forms

\begin{tabular}{|l|l|l|l|l|l|l|l|}
\hline \multirow{2}{*}{$\begin{array}{l}\text { Verb } \\
\text { stem }\end{array}$} & Sf1 & Sf2 & Sf3 & Sf4 & Sf5 & Sf6 & Sf7 \\
\cline { 2 - 7 } obligatory & Asp1 & TRVR & Asp2/AM & ANA & Asp3 & Tense & mood+agr; mod; evid \\
\hline & & & & & $\begin{array}{l}\text { obligato y (but zero exponence } \\
\text { possible }\end{array}$ & \\
\hline
\end{tabular}

Table 2: The suffix (Sf) string of Harakmbut finite verb forms (cf. Tripp 1976a) 


\section{Harakmbut finite verb form and evidentiality}

- Experiential type of evidentiality: indicating whether the speaker witnessed the event denoted by the verb form (VISual) or not (NonVISual)

- restricted to declarative contexts (but see below)

- Sf7: EVID in complementary distribution with mood+agreement suffixes and epistemic suffixes :

(1) on-a i-ma-ning-to-wa-me-te( $\left.{ }^{*}-n e\right)$ wa-knda ken-tewapa

2SG-NOM 2SG-VPL-BEN-SOC-go-REC-NVIS(*-IND) NMLZ-egg 3-BEN

'You (sg) took along eggs for them.' (speaker did not see it happen) 


\section{Harakmbut finite verb form and evidentiality}

- Sf6: tense slot $\rightarrow$ distinction between (cf. Tripp 1976a, 1995: 221-222; pace Helberg 1984: 277):

- present (zero-marked)

- future (-apo)

- recent past (-me) (cf. (1), (2))

- distant past tense (-uy) (cf. (3))

- past forms: obligatorily marked for experiential evidentiality:

- visual (zero-marked, cf. (2))

- non-visual (marked by -(a)te suffixed to -me (1) and -uy (3), or by portmanteau -tuy (5))

(2)

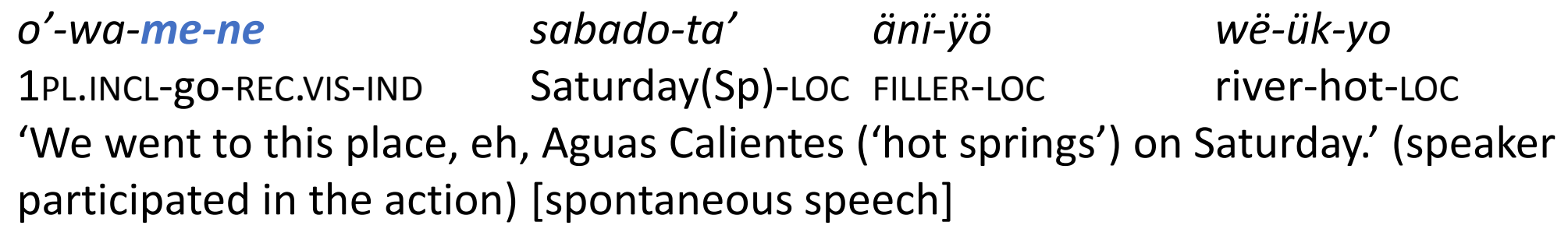




\section{Harakmbut finite verb form and evidentiality}

- past forms: obligatorily marked for experiential evidentiality:

- visual: zero-marked, cf. (2)

- non-visual: marked by -(a)te suffixed to -me (1) and -uy (3), or by portmanteau -tuy (4)

(2)

$\begin{array}{llll}o^{\prime}-\text { wa-me-ne } & \text { sabado-ta' } & \ddot{a} n і ̈-\ddot{y} 0 ̈ & \text { wë-ük-yo } \\ \text { 1PL.INCL-go-REC.VIS-IND } & \text { Saturday(Sp)-LOC } & \text { FILLER-LOC } & \text { liquid-hot-LOC }\end{array}$

'We went to this place, eh, Aguas Calientes ('hot springs') on Saturday.' (speaker participated in the action) [spontaneous speech]

(3) hak-'udn-ya o-ti-kot-uy-ate wëÿ-pa'-a house-upper.back-LOC 3SG.IND-UP-fall-DIST.PST-NVIS tree-CLF:rod-NOM 'A branch fell on the roof long ago.' (speaker did not see it happen)

(4) O'-wek-tuy keme 3SG.IND-pierce-DIST.PST.NVIS tapir 'He pierced a tapir (long time ago).' (speaker did not see it happen) 


\section{Constructional effect of NVIS: involuntary action}

(4)

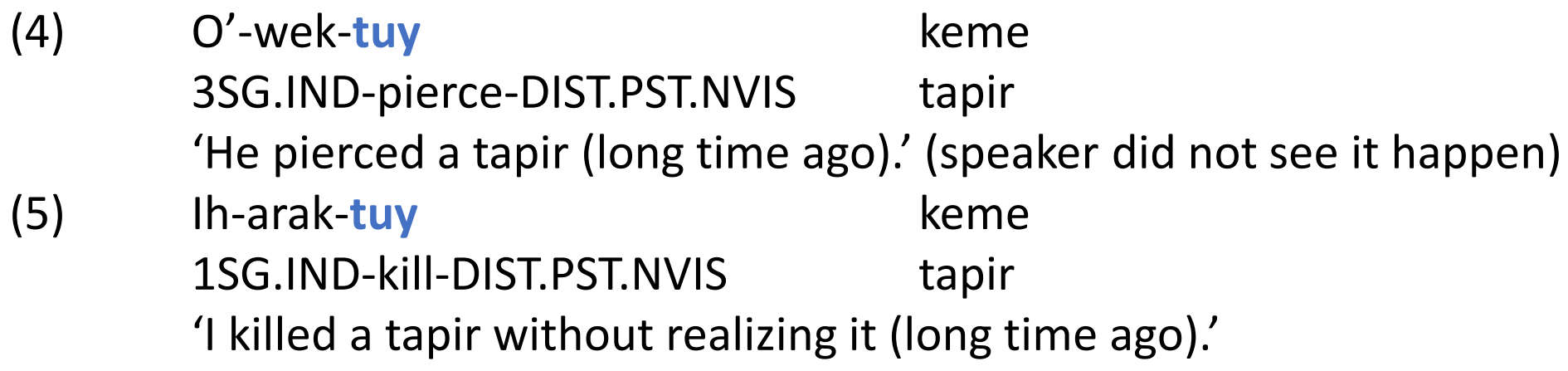

- NVIS $+1^{\text {st }}$ person Agent $\rightarrow$ interpretation of involuntary action, cf. (5)

- NVIS marks a shift away from the speaker (Sp has no experiental access)

$\rightarrow$ clash in interpretation in (5): Sp is signalled not to have witnessed the action, yet Sp is presented to have directly participated in the action as an agent, and should therefore have firsthand knowledge of it

- cxnal effect described before for a number of (other) Amazonian (e.g. Tariana, Jarawara), Bodic (Sino-Tibetan), and Athapaskan languages, and Kolyma Yukaghir (DeLancey 1985; Curnow 2003; Maslova 2003; Aikhenvald 2004; see Fauconnier 2012) 


\section{Constructional effect of NVIS: involuntary action}

(5)
Ih-arak-tuy
keme
1SG.IND-kill-DIST.PST.NVIS
tapir
'I killed a tapir without realizing it (long time ago).'

- NVIS marks a shift away from the speaker (Sp has no experiental access)

$\rightarrow$ clash in interpretation in (5): Sp is signalled not to have witnessed the action, yet Sp is presented to have directly participated in the action as an agent, and should therefore have firsthand knowledge of it

- effect explained in terms of endpoint emphasis by DeLancey (1985): evidential marking that shifts away from the speaker implies that knowledge about the phases leading up to the endpoint of the event is not accessible, in cases like (5) because the Agent is engaged non-voluntarily.

- descriptive validity of Vandelanotte's (2016) proposal:

$\rightarrow$ effect of clash between deictic and cognitive perspective? 


\section{Constructional effect of NVIS: involuntary action}

(6)

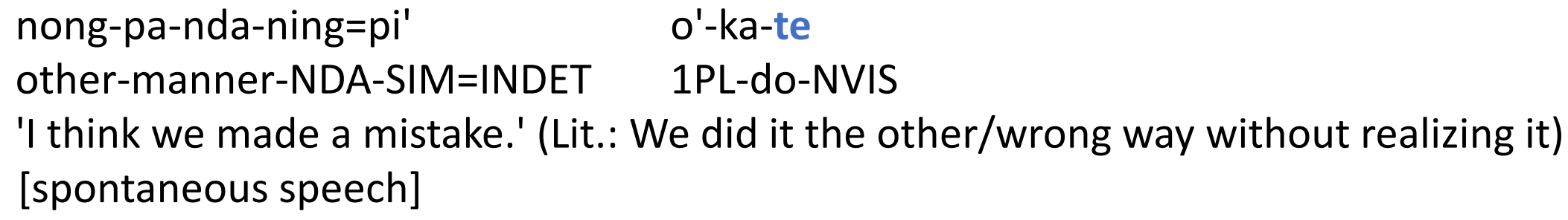

- NVIS extremely infrequent in interrogative sentences; yet (7) with 2SG subject:

(7)

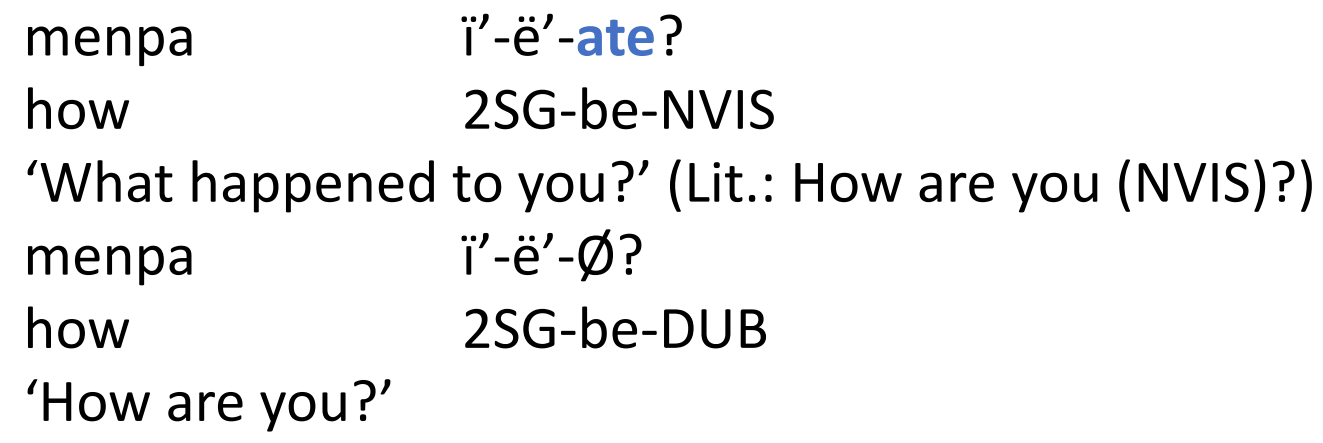

- Subject in (7)-(8): thematic role of Theme rather than Agent

- NVIS in (7) again leads to an interpretation of reduced control on the part of the subject participant 


\section{Constructional effect of NVIS: involuntary action}

(6)
nong-pa-nda-ning=pi'
o'-ka-te
other-manner-NDA-SIM=INDET
1PL-do-NVIS

'I think we made a mistake.' (Lit.: We did something the other/wrong way without realizing

it) [spontaneous speech]

- NVIS extremely infrequent in interrogative sentences; yet (7) with 2SG subject:

(7)

menpa

$$
\text { ï'-ë'-ate? }
$$

2SG-be-NVIS

'What happened to you?' (Lit.: How are you (NVIS)?)

(8)

$\begin{array}{ll}\text { menpa } & \ddot{I}^{\prime}-\ddot{e}^{\prime}-\varnothing ? \\ \text { how } & \text { 2SG-be-DUB }\end{array}$

'How are you?'

- Subject in (7)-(8): thematic role of Theme rather than Agent

- NVIS in (7) again leads to an interpretation of reduced control on the part of the subject participant parallel with egophoricity systems: cxnal effect only available to cnxs with informant = subject:

in $\mathrm{Q}$, first-hand knowledge resides with $\mathrm{H}$; with NVIS, Sp anticipates that $\mathrm{H}$ may not have full knowledge (esp. of stages leading up to present situation) 


\section{Constructional effect of NVIS: completion}

(9) o'-sik-ate

3SG.IND-black-NVIS

'It has become dark.' Alternatively (post-contact meaning): 'Good evening!'

- temporal verbs referring to the cycle of the sun (often subsumed under meteorological predications, e.g. in Malchukov \& Siewierska 2011) sometimes (NOT always) carry non-visual evidential marking

- however, the events referred to are clearly visible to the speaker $\rightarrow$ why?

- effect explained in terms of endpoint emphasis by DeLancey (1985): evidential marking that shifts away from the speaker implies that knowledge about the phases leading up to the endpoint of the event is not accessible, in contrast to knowledge about resultant state

$\rightarrow$ emphasis on completion of event

(Note that completive aspect marking is also found to signal involuntary action in a number of languages, e.g. Kannada, Bengali, Japanese, Korean, Burmese, cf. Fauconnier 2012, 2013) 


\section{Constructional effect of NVIS: completion}

(9) o'-sik-ate

3SG.IND-black-NVIS

'It has become dark.' Alternatively (post-contact meaning): 'Good evening!'

- effect explained in terms of endpoint emphasis by DeLancey (1985): evidential marking that shifts away from the speaker implies that knowledge about the phases leading up to the endpoint of the event is not accessible, in contrast to knowledge about resultant state

$\rightarrow$ emphasis on completion of event

- also completion in terms of discourse/chain of actions:

- as a castellanisized greeting: a return greeting is expected (also o'sikate), but nothing else

- as an observation: does not form startingpoint for subsequent action, unlike semantically similar form in -nde:

$$
\begin{array}{lll}
\text { O'-sik-nde } & \text { an-mba-kudn } & \text { hak-yo } \\
\text { 3SG.IND-black-ALREADY } & \text { 2PL.IMP-VPL-enter } & \text { house-LOC } \\
\text { 'It has become dark already; enter (you all) into your house.' }
\end{array}
$$




\section{Conclusion}

- Constructional effects of non-visual evidential marking in Harakmbut:

- Effect 1: NVIS $+1^{\text {st }}$ person Agent $\rightarrow$ involuntary action

- Effect 2: NVIS + impers. pred. $\rightarrow$ completion

- Origin in clash in interpretation: use of non-visual marking marks a shift away from the speaker, while events referred to ('normally') are clearly visible

- effects explained in terms of endpoint emphasis by DeLancey (1985): evidential marking that shifts away from the speaker implies that knowledge about the phases leading up to the endpoint of the event is not accessible, in contrast to knowledge about resultant state

- Effect 1: extension of evidentiality to semantic domain of volitionality (event-related) (operates on an egophoric basis; deictic vs. cognitive perspective)

- Effect 2: extension of evidentiality to the aspectual domain 
- Adelaar, W. 2000. Propuesta de un nuevo vínculo genético entre dos grupos lingüísticos indígenas de la Amazonía occidental: Harakmbut y Katukina. In Actas del I Congreso de Lenguas Indígenas de Sudamérica, L. Miranda Esquerre (ed.), vol. 2, 219-236. Lima: U. Ricardo Palma.

- Adelaar, W. 2007. Ensayo de clasificación del katawixí dentro del conjunto harakmbut-katukina. In A. Romero-Figueroa, A. Fernández Garay, A. Corbera Mori (eds.), Lenguas indígenas de América del Sur: Estudios descriptivo-tipológicos y sus contribuciones para la lingüística teórica, 159-169. Caracas: Universidad Católica Andrés Bello.

- Aikhenvald, Alexandra Y. 2004. Evidentiality. Oxford University Press.

- Crevels, M. \& H. van der Voort. 2008. The Guaporé-Mamoré region as a linguistic area. In From linguistic areas to areal linguistics, P. Muysken (ed.), 151-79. Amsterdam: Benjamins.

- Curnow, Timothy Jowan. 2003. Nonvolitionality expressed through evidentials. Studies in Language 27(1). 39-59.

- DeLancey, Scott. 1985. Lhasa Tibetan evidentials and the semantics of causation. BLS 11. 65-72.

- Dryer, Matthew S. \& Haspelmath, Martin (eds.) 2013. The World Atlas of Language Structures Online. Leipzig: Max Planck Institute for Evolutionary Anthropology. (Available online at http://wals.info, Accessed on 2016-03-10.) 
- Fauconnier, Stefanie. 2012. Constructional effects of involuntary and inanimate Agents : A cross-linguistic study. PhD dissertation, University of Leuven.

- Fauconnier, Stefanie. 2013. Completives as markers of non-volitionality. Folia Linguistica 47 (1): 35-54.

- Fonseca Solís, Gustavo. 2002. Lenguas en la Amazonía peruana. Lima: Programa FORTE-PE Ministerio de Educación.

- Guillaume, A. 2008. A grammar of Cavineña [Mouton Grammar Library no. 44]. Berlin \& New York: Mouton de Gruyter.

- Hart, R. 1963. Semantic components of shape in Amarakaeri Grammar. Anthropological Linguistics 5 (9): 1-7.

- Helberg, H. 1984. Skizze einer Grammatik des Amarakaeri. PhD dissertation, Tübingen.

- Helberg, H. 1990. Análisis functional del verbo amarakaeri. In R. Cerrón Palomino \& G. Solís Fonseca (eds.), Temas de lingüística amerindia, 227-249. Lima: Concytec.

- Matteson, E. 1972. Proto Arawakan. In E. Matteson et al. (eds.), Comparative studies in Amerindian languages, 160-242. The Hague: Mouton.

- Malchukov, Andrej \& Anna Siewierska (eds.). 2011. Impersonal Constructions: A cross-linguistic perspective. Amsterdam: John Benjamins. 
- Maslova, Elena. 2003. A grammar of Kolyma Yukaghir. Berlin: Mouton de Gruyter.

- Payne, Doris L. 1987. Noun Classification in the Western Amazon. Language Sciences 9 (1): 21-44.

- Payne, David L. 1991. A classification of Maipuran (Arawakan) languages based on shared lexical retentions. In D.C. Derbyshire \& G.K. Pullum, Handbook of Amazonian languages, Vol. 3. Berlin: Mouton de Gruyter. 355-500.

- Pozzi-Escot, Inés (ed.). 1998. El Multilingüismo en el Perú. Cuzco: CBC-SID.

- Tripp, Robert. 1976a. Los verbos Amarakaeri. Datos Etno-Lingüísticos: Colección de los archivos del ILV 33. Lima: Instituto Lingüístico de Verano.

- Tripp, Robert. 1976b. Sustantivos verbales y frases de sustantivos verbales en Amarakaeri. Datos EtnoLingüísticos: Colección de los archivos del ILV 50. Lima: Instituto Lingüístico de Verano.

- Tripp, Robert. 1976c. Las relaciones señaladas por -po y-nõk en Amarakaeri. Datos Etno-Lingüísticos: Colección de los archivos del ILV 50. Lima: Instituto Lingüístico de Verano.

- Tripp, Robert. 1995. Diccionario amarakaeri-castellano. Yarinacocha: Min. de Educación \& SIL. 
- Van linden, An. Submitted. Harakmbut. In Patience Epps \& Lev Michael (eds.), Amazonian Languages, An International Handbook. Berlin: de Gruyter Mouton.

- Vergara Romaní, Liv Kony. 2007. Las lenguas indígenas peruanas. Una panorámica histórica, estructural y sociolingüística. México: Instituto Nacional de Antropología e Historia.

- Wise, M. 1999. Small language families and isolates in Peru. In Dixon \& Aikhenvald (eds.), The Amazonian languages, 307-340. Cambridge: CUP. 


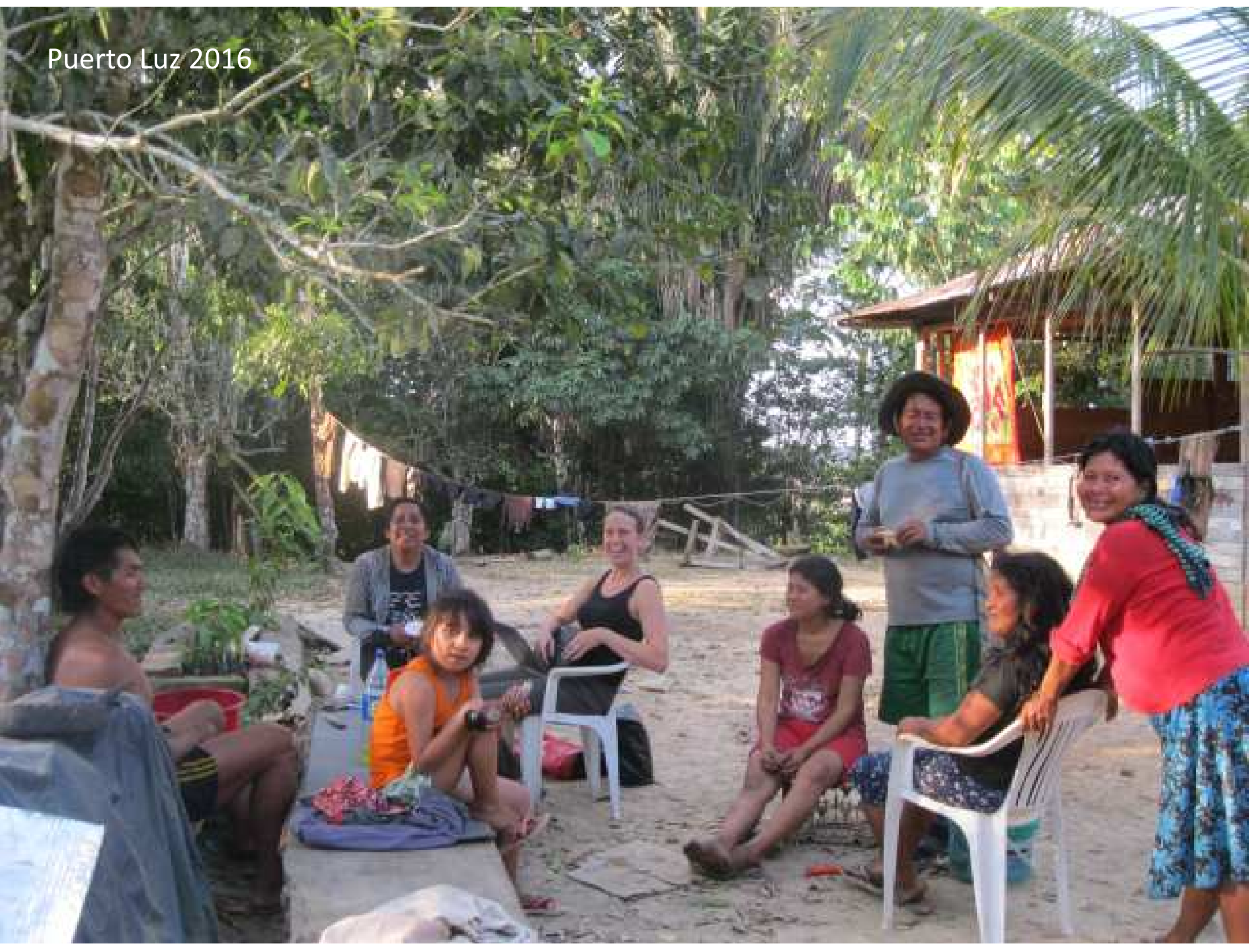

Many thanks to the Harakmbut people!

Many thanks to these funding agencies and universities: FWO, FNRS, KU Leuven, Université catholique de Louvain 